\title{
Ecological Studies on Bacteria in the Sea and Lake Waters Polluted with Organic Substances-III Growth Kinetics of the Bacterial Populations Showing Different Responses to Dissolved Organic Substances
}

\author{
Yuzaburo IsHIDA ${ }^{* 1}$ and Hajime KADOTA ${ }^{* 1}$ \\ (Received May 30, 1975)
}

\begin{abstract}
By the use of a chemostat the growth kinetics of two different bacterial populations which showed different responses to dissolved organic substances in the natural sea water was studied. The kinetics constants for the growth of Z1-bacteria, grown on a nutrientrich medium, were: $K_{s}=3.0 \mathrm{mg} \mathrm{C} / l$ and $\mu_{m}=0.19 \mathrm{~h}^{-1}$, and those for the growth of $\mathrm{Z} / 20$ bacteria, grown on nutrient-poor medium, were: $K_{s}=1.2 \mathrm{mg} \mathrm{C} / l$ and $\mu_{m}=0.15^{-1}$. Based on these data the relationship between the structure of bacterial community in the sea and the concentration of organic substances in sea water is discussed.
\end{abstract}

In the previous paper ${ }^{1 /}$ we showed by use of a chemostat that the concentration of dissolved organic substances had a great influence on the bacterial flora in sea water, and that the bacteria which grew well on nutrient-rich agar plates were predominant in the polluted sea water and the bacteria which grew well on nutrient-poor media were so in the unpolluted sea water. These results suggest that the two different bacterial populations were competing for the growth substrates in the sea water and that the growth rates of the populations were dependent upon the concentrations of organic substrates. ${ }^{2}$

In this paper we attempted a study on the growth kinetics of the above-mentioned two bacterial populations by using a chemostat in order to make clear the mechanism involved in the competition of these two bacterial populations in natural sea water.

\section{Materials and Methods}

In this experiment four sets of chemostat systems were used. The culture vessels were charged with $500 \mathrm{~m} l$ of unsterilized raw sea water, which was collected at station $\mathrm{A}^{4}$ (a heavily polluted station, DOC ${ }^{* 2}: 5.0 \mathrm{mgC} / \mathrm{l}$ ) in Osaka Bay on December 5, 1973, and filtered through $20 \mu$ mesh stainless steel net to remove detrital particles and zooplankters. The reservoir $\mathrm{R}_{1}$ was filled with $3,000 \mathrm{~m} l$ of the sterilized sea water sample which was collected at the same station. The reservoir $\mathrm{R}_{2}$ was filled with $3,000 \mathrm{~m} l$ of the diluted sea water which consisted of one part of the polluted sea water and four parts of the unpolluted sea water (DOC: $1.0 \mathrm{mg} \mathrm{C} / l$ ). The reservoir $\mathrm{R}_{3}$ was filled with $3,000 \mathrm{~m} l$

*1 Laboratory of Microbiology, Department of Fisheries, Kyoto University, Kyoto, Japan (石田祜 三郎・門田 元：京都大学辰学部)

*2 DOC means dissolved organic carbon. 
of the diluted sea water which consisted of one part of the polluted sea water and forty nine parts of the unpolluted sea water. The reservoir $\mathrm{R}_{4}$ was filled with $3,000 \mathrm{~m} l$ of the unpolluted sea water. All the sea water samples used for the reservoirs were sterilized before being charged. Sterilization was performed by filtering the water sample through a IMillipore filter having $0.22 \mu$ pore size. The dilution rate was adjusted to 0.10 $0.11 \mathrm{~h}^{-1}$. The incubation temperature was adjusted to the in situ water temperature of the station at which the water sample was collected $\left(12^{\circ} \mathrm{C}\right)$. Viable count of Z1-bacteria which grew on Z1-medium (nutrient-rich medium) plate and that of Z/20-bacteria which grew on $\mathrm{Z} / 20$-medium (nutrient-poor medium) plate ${ }^{4)}$ were made with the sea water in culture vessels at intervals of $5 \mathrm{hr}$ during the incubation. A $0.1 \mathrm{ml}$ portion of water sample taken from the culture vessel was smeared on $\mathrm{Z1-}$ and $\mathrm{Z} / 20$-agar plates. Incubation of the plates was made at $15^{\circ} \mathrm{C}$. The number of colonies on the plate was counted after being incubated for 2 or 3 weeks.

\section{Results and Discussion}

The number of bacteria grown on Z1- and Z/20-agar plates were plotted against the time of incubation (Fig. 1). According to the equation of $\mathbf{J}_{\text {ANNASCH }}(1)^{3)}$, actual growth rates were calculated from the washout rates $1 / t \ln \left(x / x_{0}\right)$.

$$
\mu=D+\frac{1}{t} \ln \left(\frac{x}{x_{0}}\right)
$$

Where $x_{0}=$ population density $(\mathrm{cell} / \mathrm{m} l)$ at zero time $(t=0), \mu=$ specific growth rate $\left(\mathrm{h}^{-1}\right)$ and $D=$ dilution rate $\left(\mathrm{h}^{-1}\right)$.

Relationship between the growth rates and the concentrations of limiting substrate

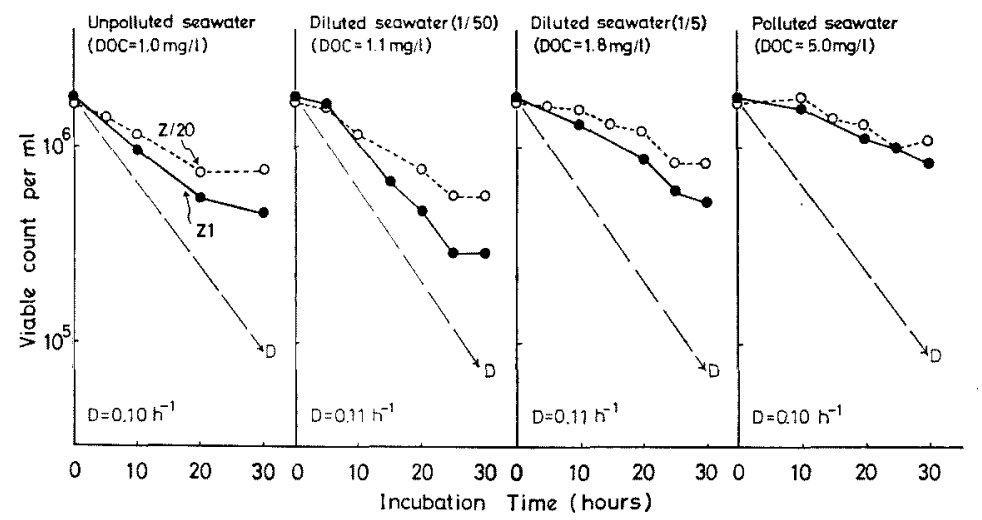

Fig. 1. Relationships between the washout rates as a function of incubation time of $\mathrm{Zl}$-bacteria and those of $Z / 20$-bacteria in the chemostats which were fed with sea water containing dissolved organic carbon in different concentrations. - $-\mathrm{Z} 1$-bacteria; $\mathrm{O}-\mathrm{O}, \mathrm{Z}$ l 20-bacteria. 
was illustrated in Fig. 2. The results indicate that the competition between populations of $\mathrm{Z1}$ - and $\mathrm{Z} / 20$ - bacteria is dependent on the concentration of organic substances as nutrients. The saturation curves of both the populations crossed at the concentration of about $5.0 \mathrm{mg} \mathrm{C} / l$. When the concentration is less than $5.0 \mathrm{mg} \mathrm{C} / l$, population of $\mathrm{Z} / 20$-bacteria will be predominant. These growth rates were obtained with sea water samples collected during early winter season. In summer season, however, the growth rates of population of Z1-bacteria were found to be $0.130 \mathrm{~h}^{-1}$ in the case of $6.0 \mathrm{mg}$ $\mathrm{C} / l\left(25^{\circ} \mathrm{C}\right)$ and $0.030 \mathrm{~h}^{-1}$ in the case of $1.2 \mathrm{mg} \mathrm{C} / l\left(20^{\circ} \mathrm{C}\right)$ respectively. But the populations of $\mathrm{Z} / 20$-bacteria were $0.095 \mathrm{~h}^{-1}$ in the case of $6.0 \mathrm{mg} \mathrm{C} / l$ and $0.090 \mathrm{~h}^{-1}$ in the case of $1.2 \mathrm{mg} \mathrm{C} / l$. These results suggest that the competition between the above-mentioned bacterial populations will be more remarkable when the water temperature becomes higher.

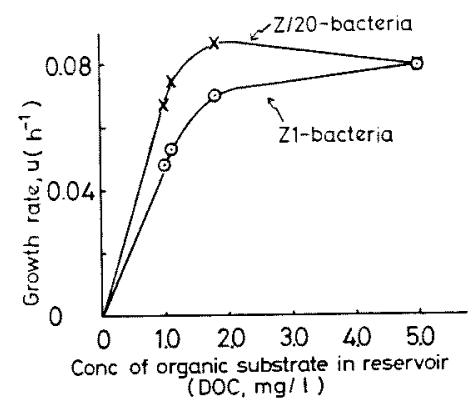

Fig. 2. The growth rate-substrate concentration relationships of $\mathrm{Z1}$ - and $\mathrm{Z} / 20$-bacteria.

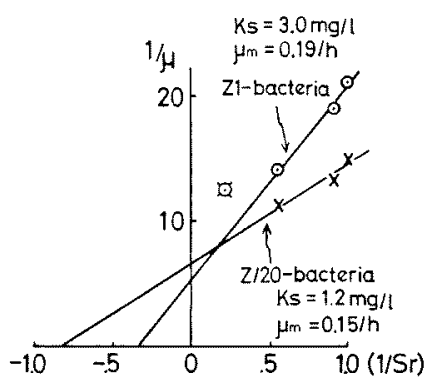

Fig. 3. Reciprocal plots for the populations of ZI- and Z/20-bacteria.

Reciprocal plots for the populations of $\mathrm{Z1-}$ and $\mathrm{Z} / 20$-bacteria were shown in Fig. 3. Kinetics constants for the growths of both the populations $(Z 1$ and $Z / 20$ ) were roughly estimated to be as follows, respectively:

$$
\begin{aligned}
K_{\mathrm{s}}^{A} & =3.0 \mathrm{mg} \mathrm{C} / l \text { and } \mu_{m}^{A}=0.19 \mathrm{~h}^{-1} \text { (population of Z1-bacteria), } \\
\text { and } K_{\mathrm{s}}^{B} & =1.2 \mathrm{mg} \mathrm{C} / l \text { and } \mu_{m}^{B}=0.15 \mathrm{~h}^{-1} \text { (poulation of Z/20-bacteria). }
\end{aligned}
$$

The data revealed that the larger $\mu_{m}$ was associated with the larger $K_{s}$, and the smaller $\mu_{m}$ was associated with the smaller $K_{8}$. Accordingly, the population of Z1-bacteria exhibited lower affinity toward organic substances at the low concentrations and the population of Z/20-bacteria showed higher affinity for organic substrates at the low concentrations. It is interesting that $\mathrm{JANNASCH}^{5}$ arrived at the same conclusions by using the mixed cultures of pure strains of aquatic bacteria.

When the growth constants $\mu_{m}, K_{8}$ and $Y$ (cell yield coefficient) are known, the steadystate concentration $(X)$ of bacterial population in the culture vessel can be predicted from the dilution rate (D) and concentration of inflowing substrate $\left(S_{r}\right)$, according to the following equation (2) 


$$
K_{s} \frac{D}{\mu_{m}-D}=S_{r}-\frac{X}{Y}
$$

When the population density of Z1-bacteria is $X^{A}$ and that of $Z / 20$-bacteria is $X^{B}$, the condition in which the $\mathrm{Zl}$-bacteria become predominant in place of the $\mathrm{Z} / 20$-bacteria is,

$$
X^{A}>X^{B}
$$

By substituting (2) for (3)

$$
D>\frac{\mu_{m}^{B} K_{s}^{A}-\mu_{m}^{A} K_{s}^{B}}{K_{s}^{A}-K_{s}^{B}}
$$

In this case the dilution rate to satisfy (3) is more than 0.11 per hour, when $Y^{A}$ of the population of $\mathrm{Zl}$-bacteria is equal to $Y^{B}$ in the population of $\mathrm{Z} / 20$-bacteria. In the case of $Y^{A}>Y^{B}$, the dilution rate for satisfying (3) will be less than 0.11 .

These experiments revealed that the structure of bacterial community in the sea is intensely controlled by the concentrations of organic substances in sea water. Further studies on the effects of molecular species of organic compounds and those of the other environmental factors on the structure of bacterial community in the sea water are now in progress.

\section{References}

1) Y. IsHIDA \& H. KaDOTA: This Bull. 41, 957-960 (1975).

2) H. G. Schlegel \& H. W. Jannasch: Ann. Rev. Microbiol., 21, $49-69$ (1967).

3) H. W. JANNASCH: J. Bacteriol., 99, 156-160 (1969).

4) Y. IsHIDA \& H. KADOTA: This Bull. 40, 999-1005 (1974).

5) H. W. JanNasch: Arch. Mikrobiol., 59, 165-173 (1967). 